\title{
Analysis of Biohydrogen Production Potential from Organic Wastes Generated in Korea
}

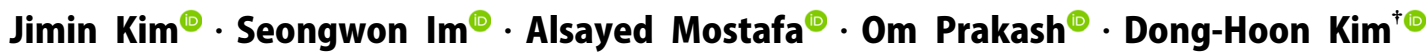 \\ ${ }^{1}$ Department of Smart-city Engineering, Inha University, Republic of Korea
}

(Received August 19, 2021; Revised September 9, 2021; Accepted September 13, 2021)

Objectives: To mitigate greenhouse gas (GHG) emissions, our country is trying to replace fossil fuel to hydrogen $\left(\mathrm{H}_{2}\right) . \mathrm{H}_{2}$ has higher energy yield $(122 \mathrm{MJ} / \mathrm{kg}$ ) than other energy sources (natural gas, coal, etc.), and is considered a clean fuel that produces only water upon combustion. The water electrolysis using renewable energy is one of the green- $\mathrm{H}_{2}$ producing methods, but its unstable characteristics depending on weather condition impede its practical application. Therefore, to establish green- $\mathrm{H}_{2}$ society, the use of waste and biomass is essential to fulfil the demand.

Methods: In this study, we estimated the biohydrogen potential of organic solid wastes: food waste, livestock manure, and sewage sludge, which are the main feedstock of domestic biogas plant. For the $\mathrm{H}_{2}$ generation process, dark fermentation (DF) and steam biogas reforming (SBR) were considered.

Results and Discussion: The potential amount of $\mathrm{H}_{2}$ through DF and SBR was 44,000 ton/y and 675,000 ton/y, respectively. The GHG reducing potential was estimated to be 5 million tons $\mathrm{CO}_{2}$-eq/year, but it can be lowered down to 2 million tons $\mathrm{CO}_{2}$-eq/year, considering the energy consumption during $\mathrm{H}_{2}$ generation process. Among the energy potential of produced $\mathrm{H}_{2}, 7 \%$ and $60 \%$ is required for $\mathrm{H}_{2}$ production in DF and SBR, respectively.

Conclusion: The expected biohydrogen production was 718,000 ton/y which can account for about $14 \%$ of the domestic $\mathrm{H}_{2}$ production target in 2040 (526 million tons). The main source was livestock manure (86\%), and minor fraction was from food waste $(10 \%)$, and sewage sludge $(4 \%)$. The GHG reducing potential was estimated to be 2 million tons $\mathrm{CO}_{2}$-eq/year, considering the energy consumption during $\mathrm{H}_{2}$ generation process.

Keywords: Hydrogen, Organic wastes, Dark fermentation, Methane steam reforming, Steam biogas reforming 


\title{
연구논문
}

\section{국내 유기성폐기물의 바이오수소 잠재량 분석}

\section{김지민 ${ }^{\circledR}$ - 임성원 ${ }^{\circledR}$. 알사예드 ${ }^{\circledR} \cdot$ 프라카시옴 ${ }^{\circledR} \cdot$ 김동훈 $^{\circledR}$}

\author{
인하대학교 스마트시티공학과
}

목적 : 우리나라는 지구온난화의 가속을 줄이기 위해 온실가스 배출량을 저감시키는 방법 중 하나로 화석연료 사용 량의 일부를 수소 에너지로 대체하기 위해 지속적으로 노력하고 있다. 수소는 천연가스, 석탄 등의 다른 에너지원 에 비해 높은 발열량 $(122 \mathrm{MJ} / \mathrm{kg})$ 을 가지고 있으며 연소 시 온실가스를 배출하지 않는 청정에너지원으로 주목받고 있지만, 현재 국내의 그린수소 생산방법인 재생에너지원을 이용한 수전해 방식은 기후조건에 영향을 받기 때문에 공급량이 불안정하다는 문제점이 있다. 본 연구에서는 수소 생산량을 보완하기 위한 방법으로 폐자원·바이오매스 중 기존 바이오가스화 시설과 연계할 수 있는 유기성폐기물(음식물류폐기물, 가축분뇨, 하수슬러지)로부터 회수 가 능한 수소 잠재량을 산정하였고, 이에 따른 온실가스 저감효과를 파악하고자 하였다.

방법 : 유기성폐기물로부터 생산할 수 있는 수소 잠재량을 산정하기 위해 유기성폐기물의 국내 연간 발생량과 일반 적인 유기물 성상을 이용하여 암발효와 바이오가스 개질 공정을 통해 생산될 수 있는 연간 수소 잠재량을 산정하 였으며, 생산된 수소를 화석연료 대체 에너지원으로 사용하였을 때 저감시킬 수 있는 온실가스양을 산출하였다.

결과 및 토의: 유기성폐기물의 연간 발생량과 기초 성상을 이용하여 암발효와 바이오가스 개질공정을 통해 생산될 수 있는 수소양은 각각 연간 4 만톤, 67 만톤이며, 유기성폐기물 종류별 수소 생산량은 가축분뇨 $86 \%$, 음식물류폐기 물 $10 \%$, 하수슬러지 $4 \%$ 순으로 산정되었다. 총 수소 생산량은 연간 72 만톤으로 2040 년도 국내 수소생산 목표량의 약 $14 \%$ 를 차지할 수 있다. 생산된 바이오수소의 온실가스 저감으로서의 가치는 총 500 만톤 $\mathrm{CO}_{2}$-eq이다. 수소 제 조 공정 시 소모되는 전력에 따른 온실가스 배출량을 고려하면, 암발효의 경우 수소생산전력의 $7 \%$, 바이오가스 개 질은 $60 \%$ 가 전력으로 소비되어 저감 가능한 온실가스 양은 연간 211 만톤 $\mathrm{CO}_{2}$-eq으로 파악되었다.

결론: 본 연구는 국내 대표적 유기성폐기물로부터 생산 가능한 바이오수소 잠재량을 분석한 최초의 결과로서, 향 후 폐자원/바이오매스 활용 그린수소 정책 계획에 적극적으로 활용이 가능할 것으로 판단된다.

주제어 : 수소, 유기성폐기물, 암발효, 메탄 수증기 개질, 바이오가스 개질

\section{1. 서론}

석탄, 석유, 천연가스 등의 화석 연료 중심의 에너지 산업구 조로 인해 대기 중 온실가스 농도가 증가하여 산업화 이전 (1850-1900) 대비 현재 약 $1^{\circ} \mathrm{C}\left(0.8-1.2^{\circ} \mathrm{C}\right)$ 의 지구 평균 온도가 상승한 것으로 추정되고 있다. 현재 진행되는 속도로 지구온 난화가 지속되면 2030-2052년 사이 전 지구 평균 온도는 $1.5^{\circ} \mathrm{C}$ 이상 상승해 이상 고온과 호우 및 가뭄 증가 등의 이상기후가 발생할 가능성이 높아질 것으로 예상된다. ${ }^{1)}$ 온실가스로 인한 지구온난화의 가속을 줄이기 위해 국제기구인 유엔 기구에서 체결한 1997년 교토의정서와 2015년 채택된 파리협정에 의해 전 세계적으로 온실가스 배출량 감소 목표를 설정하였다. 국 내에서도 2050년 탄소중립 목표를 선언하고, 2030년까지 온 실가스 예상 방출량인 851 백만톤 $\mathrm{CO}_{2}$-eq의 $30 \%$ (315백만톤)
감축목표를 수립하였다. ${ }^{2,3)}$

이와 같은 목표를 이루기 위한 전략 중 하나로 국가적인 차 원에서 에너지 경제구조를 화석연료에서 수소 위주의 에너지 경제로 전환시키는 것을 목표로 하는 ‘수소 경제’를 도입시키 기 위해 노력하고 있다. 수소는 천연가스, 디젤, 석탄 등의 다 른 에너지원에 비해 높은 발열량 $(122 \mathrm{MJ} / \mathrm{kg})$ 을 가지고 있으며 연소 시 이산화탄소 등의 온실가스를 배출하지 않는 청정에너 지원으로 각광받고 있다. ${ }^{4)}$ 특히 재생에너지로 생산하는 '녹색 수소(Green Hydrogen)'의 비중을 2040년까지 총 수소 생산량 의 $70 \%$ 로 높이려는 계획을 가지고 있다. 하지만 현재 국내 수소 생산의 약 $99 \%$ 가 천연가스, $\mathrm{LPG}$ 등을 이용한 회색수소 (Grey Hydrogen) 생산 방식이며, 수전해와 폐자원/바이오매 스를 이용한 친환경 수소 생산방식은 상용화되어있지 않다. ${ }^{5)}$ 전 세계적으로 수소 생산 원료의 $96 \%$ 를 화석 연료(천연가스 
$48 \%$, 석유 $30 \%$, 석탄 $18 \%$ )가 차지하고, 수전해를 이용한 수 소 생산은 $4 \%$, 폐자원/바이오매스를 이용한 수소 생산은 미비 한 실정이다. ${ }^{0}$ 따라서 현재의 수소 생산방식은 대부분 화석연 료로부터 생산되어 생산과정에서 발생된 이산화탄소를 포집 하는 과정 없이는 청정에너지로 인정받기 어렵기 때문에 생산 과정에서 온실가스가 생산되지 않는 그린 수소의 비중을 높이 는 것이 중요하다.

환경친화적인 수소 생산방법의 생산 원료로는 크게 물(수전 해)과 폐자원/바이오매스 등의 재생자원으로 나눌 수 있다. 그 린 수소로서의 수전해는 태양열, 풍력 등으로 생산된 재생에 너지원으로부터 공급되는 전기로 물을 분해해 수소를 생산하 는 Power to Gas (P2G) 기술로서 국내에서는 현재까지 재생 에너지 생산이 날씨 등에 영향을 받아 에너지 공급이 안정적 이지 않기 때문에 생산량이 일정하지 않다는 문제가 발생한 다. ${ }^{78)}$ 한편, 폐자원/바이오매스는 배출량이 일정하며, 환경오 염물질을 처리한다는 장점이 있으며 현재 국내 연구 현황으로 는 가스화 공정 파일럿 개발 단계, 발효공정은 핵심 요소 개발 중으로 알려져 있다. ${ }^{9}$ 특히 바이오매스 중에서도 수분 함량이 많은 유기성폐기물을 이용하게 된다면 기존 바이오가스화 시 설과 연계해 수소를 생산할 수 있다.

폐자원/바이오매스를 이용한 수소 생산방법으로는 일반적 으로 1) 열화학적 전환(가스화반응) 2) 생물학적 발효(바이오 수소)로 나눌 수 있다. 열화학적 전환 방법은 바이오매스가 고온/고압에서 산소 또는 증기와 만나 수소를 포함한 합성가 스를 생성하는 가스화 반응을 주로 이용하며, 촉매 이용 시 $750-950^{\circ} \mathrm{C}$, 촉매 미이용 시에는 $1,250^{\circ} \mathrm{C}$ 이상의 온도에서 반 응이 진행된다. 하지만 이 기술은 수분 함량이 적은 $(<60 \%)$ 고체 바이오매스를 원료로 사용했을 때 적합한 기술로서 음식 물쓰레기와 같은 유기성폐기물에 적용하기에는 적합하지 않 다. ${ }^{10)}$ 생물학적 발효는 미생물을 이용하여 수소를 생산하는 방식으로 조류 또는 광합성 미생물이 빛을 이용하는 광합성반 응을 통해 수소를 생산하는 광발효와 빛이 없이 혐기성 조건 에서 혐기성 균주가 수소를 생산하는 암발효, 미생물전해전지 (Microbial electrolysis cell)로 나뉘게 된다. ${ }^{11)}$ 광발효와 미생
물전해전지 기술은 높은 수소 전환율(yield)을 얻을 수 있지만, 빛에너지와 전자를 효율적으로 얻기 위해 넓은 표면적의 반응 기 또는 전극이 필요함에 따른 비경제성과 열역학적으로 비가 역적 반응에 기인한 낮은 수소 생산속도에 따라 실용화에는 한계가 있는 상황이다. 한편, 암발효는 열역학적으로 가역적 인 반응으로서 수소 전환율은 낮지만, 생산속도가 매우 빠르 다는 장점이 존재한다. ${ }^{2)}$ 또한 암발효 공정 이후 바이오가스 화 공정을 통해 유기성폐기물 처리과정에서 생산된 바이오가 스에 포함된 메탄을 이용한 수소 생산 방법도 적용시킬 수 있다. 메탄을 수소로 전환하는 방법으로는 수증기 개질반응, 부분 산화반응, 열분해, 이산화탄소 개질반응 등이 사용되며, 수증기 개질 반응이 가장 경제적이고 상용화되어있는 공법으 로 알려져 있다. ${ }^{13-15)}$

본 연구에서는 재생에너지원이며 환경친화적인 수소 생산 원료인 유기성폐기물을 이용해 1) 암발효 공정 2) 바이오가스 화 + 메탄 수증기 개질 공정(바이오가스 개질 공정)의 순서로 수소를 생산하며(Fig.1), 연간발생량 및 원료 성상과 각 기술 별 수소 생산효율을 이용해 수소 생산량을 산정해 국내 목표 생산량에 기여할 수 있는 잠재량을 산출하였다. 또한 수소생 산의 첫 번째 공정인 암발효의 가온, 교반, 펌프 이용과 바이 오가스 개질의 가온, 가스 압력 상승, 냉각 등에 의해 소모되 는 에너지를 통해 생산 공정에서 발생되는 온실가스양을 고려 하여 생산된 수소를 화석연료를 대체한 에너지원으로 사용했 을 때 저감시킬 수 있는 온실가스 저감량을 알아보았다.

\section{2. 분석방법}

\section{1. 국내 주요 유기성폐기물 배출량}

유기성폐기물에는 목재, 농축산부산물, 유기성산업폐수 등 도 포함될 수 있지만, 본 연구에서는 국내 바이오가스화 플랜 트에 주로 공급되고 있는 음식물류폐기물, 가축분뇨, 하수슬 러지만을 고려하였다. ${ }^{16,17)}$ 각 유기성폐기물의 발생량은 2019 년 기준 자원순환정보시스템에서 발표한 '전국 폐기물 발생 및 처리현황, ${ }^{18)}$ 의 음식물류폐기물 분리배출 발생량, 환경부에

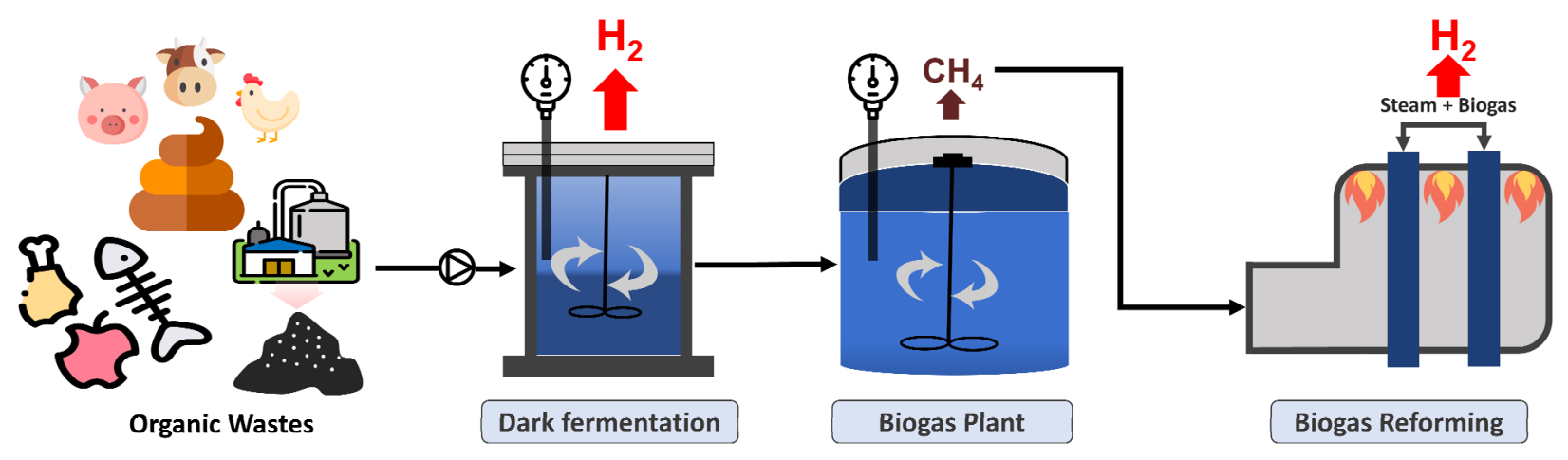

Fig. 1. Schematic diagram of biohydrogen production from organic wastes. 
Table 1. Annual domestic organic wastes production and their average properties.

\begin{tabular}{|c|c|c|c|c|c|c|}
\hline & Units & Food waste ${ }^{18,22)}$ & Pig slurry ${ }^{19,23)}$ & Cattle manure $^{19,24)}$ & Chicken manure ${ }^{19,25)}$ & Sewage sludge $20,26,27)$ \\
\hline Annual generation & ton/y & $5,224,683$ & $22,222,248$ & $22,851,845$ & $9,965,552$ & $4,221,384$ \\
\hline TS & $\mathrm{kg} / \mathrm{m}^{3}$ & 132 & 70 & 300 & 400 & 180 \\
\hline VS & $\mathrm{kg} / \mathrm{m}^{3}$ & 125 & 45 & 235 & 230 & 130 \\
\hline COD & $\mathrm{kg} / \mathrm{m}^{3}$ & 200 & 85 & 350 & 270 & 220 \\
\hline
\end{tabular}

서 발표한 '가축분뇨 발생 및 처리현황’ 통계자료 ${ }^{19}$ 에서 돈분, 한육우, 젖소, 돼지, 닭·오리의 분뇨 발생량, 환경부의 '하수도 통계’의 연간 하수케이크 발생량 ${ }^{20)}$ 의 통계자료를 인용하였 으며, 각 유기성폐기물의 연간 발생량과 성상(volatile solid (VS), chemical oxygen demand (COD))을 Table 1에 제시하였 다. 음식물류폐기물은 다른 유기성폐기물에 비해 고농도의 고형물 및 유기물 함량을 나타내고 있으며 계절별로 농도가 달라져 총 고형물(Total solid (TS))의 경우에는 약 $18 \%$ 에서 $25 \%$ 까지도 나타나며 ${ }^{21)}$, 본 연구에서는 $\operatorname{Kim}(2021)$ 의 논문을 참고하여 휘발성고형물(Volatile Solids, VS) 농도 $125 \mathrm{~kg} / \mathrm{m}^{3}$, $\mathrm{COD} 200 \mathrm{~kg} / \mathrm{m}^{3}$ 의 성상을 이용하였다. ${ }^{22)}$ 가축분뇨는 저장 상 태에 따라 농도 범위가 상당히 넓게 나타나고 돈분의 경우 대부분 액상 슬러리 상태로 저장되므로 상대적으로 TS, COD 농도가 낮게 나타나며, 계분과 우분의 경우 톱밥, 왕겨 등의 깔개의 종류에 따라 농도가 달라지며, $\mathrm{TS}$ 농도가 상대적으로 높게 나타난다. 돈분, 우분, 계분의 각 성상은 기존 문헌에 따 라 VS 45, 235, $230 \mathrm{~kg} / \mathrm{m}^{3}, \mathrm{COD} 85,350,270 \mathrm{~kg} / \mathrm{m}^{3}$ 을 이용하 였다. ${ }^{23-25)}$ 하수슬러지의 경우 하수처리과정에서 발생한 슬러 지를 탈수시켜 생성된 함수율 $80 \%$ 대의 슬러지 케이크를 Svensson et al. (2018)의 성상을 참고하여 VS $130 \mathrm{~kg} / \mathrm{m}^{3}$, $\mathrm{COD} 220 \mathrm{~kg} / \mathrm{m}^{3}$ 의 농도를 이용하여 수소와 바이오가스 생산 량을 산정하였다. ${ }^{26,27)}$

\section{2. 유기성폐기물을 이용한 바이오수소생산 방법}

\subsection{1. 암발효}

암발효는 혐기 발효 미생물을 이용해 빛이 없는 혐기 조건 에서 유기물을 혐기성 소화과정인 가수분해(Hydrolysis) 단계, 산 생성(Acidogenesis) 단계, 아세트산 생성(Acetogenesis) 단 계, 메탄 생성(Methnogenesis) 단계 총 4단계 중 메탄생성 단 계 전까지만 진행시켜 수소를 생산하는 방법으로 대표적인 미생물로는 클로스트리디움(Clostridium)과 장내세균(Enteric bacteria) 등이 있다. ${ }^{28)}$ 이론적으로 1 몰(mol)의 포도당(glucose) 이 모두 수소로 전환될 때 최대 12 몰이 생산될 수 있지만(식 (1)), 열역학적 관점에서 아세트산(Acetate)이 주된 생성물이 라 가정할 때 생산될 수 있는 최대 수소 생산량은 4 몰이며(식 (2)) 부티르산(Butyrate)이 주된 생성물일 때 최대 수소 생산량 은 2 몰이다(식 (3)). 이를 고려해 보았을 때 $1 \mathrm{~g} \mathrm{COD}$ 당 수소 전환효율은 $16 \%-33 \%$ 으로 계산될 수 있다. 하지만, 유기성
폐기물의 경우 탄수화물(Carbohydrate), 단백질(Protein), 지 방(Lipid) 등의 고분자 유기물로 구성되어 있고, 단백질과 지방에서의 수소생산 잠재량은 탄수화물에 비해 매우 낮 다. ${ }^{29)}$ 이에 따라 일반적으로 이용되는 수소전환율의 단위는 "mol $\mathrm{H}_{2} / \mathrm{mol}$ hexose"이며, 탄수화물의 함량에 따라 유기성 폐기물의 수소 잠재량은 크게 다르게 된다. 음식물류폐기물 의 탄수화물 함량이 $30-60 \%$ 정도로 가장 높으며 ${ }^{30)}$ 가축분뇨 와 하수슬러지는 $10 \%$ 미만으로 낮다.31-33) 따라서, 기존 문헌 에 따르면, 유기성폐기물에 함유된 전체 $\mathrm{COD}$ 기준 수소전환율 은 음식물류폐기물, 가축분뇨, 슬러지가 각각 7.0-9.0\% ${ }^{34-36)}$, $1.5-2.5 \%^{37,38)}, 0.5-2.5 \%^{39,40)}$ 이며, 본 연구에서는 평균값을 사 용하여 다음의 식 (4)를 통해 연간 수소 생산량을 계산하였다

(Table 2).

$$
\begin{aligned}
& \mathrm{C}_{6} \mathrm{H}_{12} \mathrm{O}_{6}+6 \mathrm{H}_{2} \mathrm{O} \rightarrow 12 \mathrm{H}_{2}+6 \mathrm{CO}_{2} \\
& \mathrm{C}_{6} \mathrm{H}_{12} \mathrm{O}_{6}+6 \mathrm{H}_{2} \mathrm{O} \rightarrow 2 \mathrm{CH}_{3} \mathrm{COOH}+4 \mathrm{H}_{2}+2 \mathrm{CO}_{2} \\
& \mathrm{C}_{6} \mathrm{H}_{12} \mathrm{O}_{6} \rightarrow \mathrm{CH}_{3} \mathrm{CH}_{2} \mathrm{CH}_{2} \mathrm{COOH}+2 \mathrm{H}_{2}+2 \mathrm{CO}_{2}
\end{aligned}
$$

$H_{2}$ production $(\mathrm{kg} / \mathrm{y})=$ Waste production (ton $/ y) \times C O D\left(\mathrm{~kg} \mathrm{COD} / \mathrm{m}^{3}\right) \times$ $\mathrm{H}_{2}$ Conversion (\%) $\times 1 \mathrm{~kg} \mathrm{H}_{2} / 8 \mathrm{~kg} \mathrm{COD}$

\subsection{2. 바이오가스 개질}

유기성폐기물로부터 생산 가능한 바이오가스양을 알아보기 위해, 본 연구에서 활용한 바이오가스화 효율은 국내 바이오 가스 기술 수준(Table 2)과 암발효 공정에서 생산되는 수소 생산량을 고려하여 산정하였다. 음식물류폐기물의 바이오가 스 효율의 경우 '통합처리 바이오가스화 시설의 기술지침서'

Table 2. General biogas yield of organic wastes via anaerobic digestion process.

\begin{tabular}{ccc} 
Organic waste type & $\begin{array}{c}\text { Biogas yield } \\
\left(\mathrm{m}^{3} \mathrm{CH} / \mathrm{kg} \text { COD }\right)\end{array}$ & Ref. \\
\hline Food waste & $0.19-0.30$ & $41)$ \\
Pig slurry & $0.14-0.28$ & \\
Cattle manure & $0.13-0.20$ & $44)$ \\
Chicken manure & $0.19-0.33$ & \\
Sewage sludge & $0.06-0.18$ & $41)$ \\
\hline
\end{tabular}


Table 3. Electricity consumption and GHG emission for operating each process, and its efficiency for hydrogen production.

\begin{tabular}{|c|c|c|c|c|c|}
\hline & Units & \multicolumn{2}{|c|}{ DF } & \multicolumn{2}{|l|}{ SBR } \\
\hline & & Pump & 1.8 & Heating & 0.9 \\
\hline \multirow[t]{2}{*}{ Electricity consumption } & $\mathrm{kWh} / \mathrm{m}^{3}$ & Mixing & 1.8 & Compression, Cooling etc. & 0.4 \\
\hline & & Total & 3.6 & Total & 1.3 \\
\hline Hydrogen production & $\mathrm{kg} \mathrm{H}_{2} / \mathrm{m}^{3}$ & \multicolumn{2}{|c|}{2} & \multicolumn{2}{|l|}{0.14} \\
\hline GHG emission & $\mathrm{kg} \mathrm{CO}{ }_{2}-\mathrm{eq} / \mathrm{kg} \mathrm{H}{ }_{2}$ & \multicolumn{2}{|c|}{0.83} & \multicolumn{2}{|l|}{4.15} \\
\hline
\end{tabular}

와 본 연구의 음식물류폐기물의 성상을 이용해 산정된 평균값 은 $0.24 \mathrm{~m}_{\mathrm{CH} 4}^{3} / \mathrm{kg} \mathrm{COD}$ 이지만 ${ }^{41)}$, 암발효 단계에서 $8 \%$ 의 $\mathrm{COD}$ 가 수소로 전환되어 남은 $92 \%$ 의 $\operatorname{COD}\left(184 \mathrm{~kg} / \mathrm{m}^{3}\right)$ 에서 바이오 가스가 생산될 수 있다. 따라서 암발효 공정을 반영한 바이오 가스 효율은 $0.22 \mathrm{~m}_{\mathrm{CH} 4}^{3} / \mathrm{kg} \mathrm{COD}\left(0.24 \mathrm{~m}^{3} \mathrm{CH}_{4} / \mathrm{kg} \mathrm{COD} \times 0.92\right)$ 으로 산정되었다. 같은 방법으로 본 연구에서 사용한 바이오 가스 효율은 돈분 $0.20 \mathrm{~m}^{3}{ }_{\mathrm{CH} 4} / \mathrm{kg} \mathrm{COD}$, 우분 $0.16 \mathrm{~m}^{3} \mathrm{CH}_{4} / \mathrm{kg}$ $\mathrm{COD}$, 계분 $0.26 \mathrm{~m}_{\mathrm{CH} 4}^{3} / \mathrm{kg} \mathrm{COD}$, 하수슬러지 $0.12 \mathrm{~m}^{3} \mathrm{CH}_{4} / \mathrm{kg}$ $\mathrm{COD}$ 을 기준으로 바이오가스 생산량을 산정하였다.

메탄가스 $\left(\mathrm{CH}_{4}\right)$ 를 수소로 전환하는 방법으로는 메탄 수증기 개질 공법을 적용하였다. 메탄 수증기 개질 공법은 주로 $700^{\circ} \mathrm{C}$ 이상의 고온 조건에서 촉매( $\mathrm{Ni}, \mathrm{Pt}, \mathrm{Rh}, \mathrm{Ru}$ 등 $\left.{ }^{42)}\right)$ 를 이용해 메탄 을 수증기와 반응시켜 수소를 생산시키는 반응이다(식 (5-7)). 이론적으로 메탄 1 몰당 최대 수소 4 몰이 생산 가능하지만 일반적인 실규모 이상의 연구에서 $70 \%$ 의 효율을 가지므로 메 탄의 수소 전환율을 $2.8 \mathrm{~mol} \mathrm{H}_{2} / \mathrm{mol} \mathrm{CH}_{4}$ 가정하여 수소 생산 량은 아래의 식 $(8,9)$ 을 이용하여 산정하였다. ${ }^{43)}$

$$
\begin{aligned}
& \mathrm{CH}_{4}+\mathrm{H}_{2} \mathrm{O} \rightarrow \mathrm{CO}+3 \mathrm{H}_{2} \\
& \mathrm{CO}+\mathrm{H}_{2} \mathrm{O} \rightarrow \mathrm{H}_{2}+\mathrm{CO}_{2} \\
& \mathrm{CH}_{4}+2 \mathrm{H}_{2} \mathrm{O} \rightarrow \mathrm{CO}_{2}+4 \mathrm{H}_{2} \\
& \mathrm{CH}_{4} \text { production }\left(m_{\mathrm{CH}}^{3} / y\right)=
\end{aligned}
$$$$
\text { Waste production(ton } / y) \times C O D\left(k g C O D / \mathrm{m}^{3}\right) \times
$$$$
\text { Biogas Conversion }\left(\mathrm{m}_{\mathrm{CH}}^{3} \mathrm{~kg} \mathrm{COD}\right)
$$

$\mathrm{H}_{2}$ production $(\mathrm{kg} / \mathrm{y})=$

$\mathrm{CH}_{4}$ production $\left(\mathrm{m}^{3} \mathrm{CH}_{4} \mathrm{y}\right) \times 2.8 \mathrm{~mol} \mathrm{H}_{2} / \mathrm{mol} \mathrm{CH}_{4} \times$ $2 \times 10^{-3} \mathrm{~kg} \mathrm{H}_{2} / \mathrm{mol} \mathrm{H}_{2} \div 22.4 \times 10^{-3} \mathrm{~m}^{3} \mathrm{CH}_{4} / \mathrm{mol} \mathrm{CH}_{4}$

\section{3. 온실가스 저감량 산정}

유기성폐기물로부터 생성된 수소를 화석연료 대체 에너지 원으로 사용해 전력을 생산했을 때 저감되는 온실가스 양과 수소생산 공정에서 소모되는 에너지를 통해 발생하는 온실 가스를 차감하여 전체 공정에서의 온실가스 저감량을 산정 하였다.

화석연료를 대체한 효과로 저감되는 온실가스를 산정하기 위 해서는 수소의 발열량 $\left(33.3 \mathrm{kWh} / \mathrm{kg} \mathrm{H}_{2}\right)$ 과 발전효율 $(45 \%)^{45,46)}$,
앞서 계산한 암발효와 바이오가스 개질 과정에서 생산된 수소의 연간 발생량을 통해 수소를 이용하여 얻을 수 있는 연간 전력량을 구할 수 있다. 국내 온실가스 배출계수 $(0.46$ $\mathrm{kg} \mathrm{CO}$-eq/kWh)는 ${ }^{47)}$, 기존 에너지원을 이용해 $1 \mathrm{kWh}$ 를 생산 할 때 발생하는 온실가스로, 이를 이용하게 되면 수소를 에너 지원으로 이용함으로써 저감될 수 있는 온실가스양을 구할 수 있다.

암발효 공정에서 고려한 에너지 소모량은 ‘음폐수 바이오 가스화 시설 운영관리 기술'의 산발효조 기기 규격을 참고해 ${ }^{48)}, 800$ 톤 규모 이상의 산발효조 운전시 이용되는 전력을 산정 하였다. 가온에서 이용되는 에너지는 수소연료전지 발전을 통 해 얻어지는 열에너지(수소 발열량의 약 $30 \%$ )로 인해 전량 회 수가 가능하여, 펌프, 교반기에 사용되는 전력만을 산정해 아 래 Table 3에 나타내었다. 이를 통해 총 소모 에너지는 유입폐기 물 $1 \mathrm{~m}^{3}$ 당 $3.6 \mathrm{kWh}$ 가 사용되며, 수소 생산량은 음식물류폐기물 을 기준으로 산정해 유입수 $1 \mathrm{~m}^{3}$ 당 $2 \mathrm{~kg}$ 이 생산되어 $1 \mathrm{~kg}$ 의 수소 를 생산하기 위해서는 $0.83 \mathrm{~kg} \mathrm{CO}$-eq의 온실가스가 발생하게 된다.

바이오가스 개질의 경우 Mihn et al. (2018)을 참고해 ${ }^{49)} 50$ $\mathrm{Nm}^{3} \mathrm{H}_{2} / \mathrm{h}$ 급 반응기를 기준으로 가온, 바이오가스 압력 증가 (압축) 및 냉각기 등에 사용되는 에너지를 고려하였다. 이때, 가온 에너지의 약 $40 \%$ 는 냉각공정에서 회수되는 열을 이용할 수 있으며, $37 \%$ 는 수소 발전으로 인해 생산되는 열에너지를 이용해 사용할 수 있는 것으로 가정하였다. 따라서 Table4의 가온에너지는 열회수를 제외한 순수하게 소모되는 가온에너 지를 나타내었다. 바이오가스 $1 \mathrm{~m}^{3}$ 당 $1.3 \mathrm{kWh}$ 의 에너지가 소 모되며, 바이오가스 $1 \mathrm{~m}^{3}$ 당 생산되는 수소 양은 $0.14 \mathrm{~kg}$ 으로 산정되어 수소 $1 \mathrm{~kg}$ 생산시 발생되는 온실가스양은 $4.15 \mathrm{~kg}$ $\mathrm{CO}_{2}$-eq이다. 암발효와 바이오가스 개질(메탄 수증기 개질)에 서의 온실가스 발생량(Table 3)과 식 (10)을 이용하여 수소생 산과정에서의 총 온실가스 발생량을 구할 수 있다. 최종적으 로 절감되는 온실가스 양은 식 (11)과 같이 수소를 에너지원으 로 사용함으로써 절감할 수 있는 온실가스양에서 수소 생산과 정에서 발생되는 온실가스양을 제외시켜 구할 수 있다.

GHG $G_{\text {Production }}\left(\mathrm{kg} \mathrm{CO}_{2}-e q / y\right)=$

$\mathrm{H}_{2}$ production by $\mathrm{DF}\left(\mathrm{kg} \mathrm{H}_{2} / \mathrm{y}\right) \times 0.83 \mathrm{~kg} \mathrm{CO}$-eq $/ \mathrm{kg}$ $\mathrm{H}_{2}+\mathrm{H}_{2}$ production by $\mathrm{SBR}\left(\mathrm{kg} \mathrm{H}_{2} / \mathrm{y}\right) \times 4.15 \mathrm{~kg}$ 
Table 4. Expected total biohydrogen production from organic wastes via dark fermentation process.

\begin{tabular}{cccccc} 
Organic waste type & $\begin{array}{c}\text { Annual generation } \\
\text { (ton/year) }\end{array}$ & $\begin{array}{c}\text { COD } \\
\text { (ton COD/year) }\end{array}$ & $\begin{array}{c}\mathrm{H}_{2} \text { production } \\
\text { (ton COD/year) }\end{array}$ & $\begin{array}{c}\mathrm{H}_{2} \text { production } \\
\text { (ton/year) }\end{array}$ & $\begin{array}{c}\text { Total H production } \\
\text { (ton/year) }\end{array}$ \\
Food waste & $5,224,683$ & $1,044,937$ & 83,595 & 10,449 \\
Livestock manure & $55,039,645$ & $12,577,736$ & 251,555 & 31,444 & 43,635 \\
Sewage sludge & $4,221,384$ & 928,704 & 18,574 & 1,741 & \\
\hline
\end{tabular}

Table 5. Expected total biohydrogen production from organic wastes via anaerobic digestion and stream biogas reforming process.

\begin{tabular}{ccccc} 
Organic waste type & $\begin{array}{c}\text { Annual generation } \\
\text { (ton/year) }\end{array}$ & $\begin{array}{c}\text { Biogas production } \\
\left(\mathrm{m}^{3} \mathrm{CH} / \text { /year) }\right.\end{array}$ & $\begin{array}{c}\mathrm{H}_{2} \text { production } \\
\text { (ton/year) }\end{array}$ & $\begin{array}{c}\text { Total } \mathrm{H}_{2} \text { production } \\
\text { (ton/year) }\end{array}$ \\
Food waste & $5,224,683$ & $229,886,052$ & 57,472 & 674,598 \\
Livestock manure & $55,039,645$ & $2,357,063,286$ & 589,266 & \\
Sewage sludge & $4,221,384$ & $111,444,538$ & 27,861 & \\
\hline
\end{tabular}

$\mathrm{CO}_{2}-\mathrm{eq} / \mathrm{kg} \mathrm{H}_{2}$

GHG $G_{\text {Reduction }}(\mathrm{kg} \mathrm{CO}-e q / y)=$

Annual $\mathrm{H}_{2}$ production $\left(\mathrm{kg} \mathrm{H}_{2} / \mathrm{y}\right) \times 33.3 \mathrm{kWh} / \mathrm{kg} \mathrm{H}_{2} \times$ $0.45 \times 0.46 \mathrm{~kg} \mathrm{CO}$-eq $/ \mathrm{kWh}-\mathrm{GHG}$ production

$(\mathrm{kg} \mathrm{CO}-e q / y)$

\section{3. 결 과}

\section{1. 수소 생산량}

\subsection{1. 암발효 수소 생산량}

암발효를 통해 생산된 수소의 연간 생산량은 Table 2에 명 시되어 있는 유기성폐기물의 연간 생산량과 $\mathrm{COD}$ 농도를 통해 연간 생성되는 전체 $\mathrm{COD}$ 양을 구한 후 각 유기성폐기물의 수소 생산효율을 통해 전환된 수소의 총 $\mathrm{COD}$ 양을 구할 수 있다. 그 후 수소는 1 몰당 $16 \mathrm{~g} \mathrm{COD}$ 에 해당하므로, $1 \mathrm{~g} \mathrm{COD}$ 당 $0.125 \mathrm{~g}$ 의 수소가 생산된다. 따라서 식 (4)의 계산방법을 통해 각 유기성폐기물의 수소 생산량을 구하면 음식물류폐기 물의 경우 연간 발생량은 5 백만톤, $\mathrm{COD}$ 농도가 $200 \mathrm{~g} / \mathrm{L}$ 이므 로 음식물 쓰레기의 총 $\mathrm{COD}$ 는 연간 104 만톤으로 $8 \%$ 의 $\mathrm{COD}$ 가 수소로 전환되어 수소의 $\mathrm{COD}$ 양은 연간 8 만톤이며 $1 \mathrm{~g}$ 의 수소가 $8 \mathrm{~g}$ 의 $\mathrm{COD}$ 를 가지므로 총 1 만톤의 수소를 생산할 수 있다. 동일한 과정을 통해 각 유기성폐기물의 수소 생산량은 가축분뇨로부터 연간 3.1 만톤, 슬러지 연간 0.2 만톤의 수소가 생산된다. 따라서 유기성폐기물을 기질로 암발효를 통해 연간 4.4만톤의 수소를 생산할 수 있다(Table 4).

\subsection{2. 바이오가스 개질 수소 생산량}

각 유기성폐기물의 연간 발생량, 물질 성상 및 바이오가스 생산효율을 통해 바이오가스 생산량을 추정한 결과 음식물류 폐기물의 바이오가스 생산효율은 $0.22 \mathrm{~m}_{\mathrm{CH} 4}^{3} \mathrm{~kg} \mathrm{COD}$ 로 총 연 간 230 백만 $\mathrm{m}_{\mathrm{CH} 4}^{3}\left(104\right.$ 만톤 $\mathrm{COD} /$ 년 $\left.\times 0.22 \mathrm{~m}_{\mathrm{CH}}^{3} / \mathrm{kg} \mathrm{COD}\right)$ 의
바이오가스가 생산되며, 가축분뇨 2,357 백만 $\mathrm{m}^{3} \mathrm{CH} 4$, 하수슬러 지 111 백만 $\mathrm{m}^{3} \mathrm{CH} 4$ 의 메탄이 생산된다. 따라서 총 연간 바이오 가스 생산량은 2,698백만 $\mathrm{m}^{3}{ }_{\mathrm{CH} 4}$ 으로 모든 바이오가스를 메탄 수증기 개질 공정을 통해 수소를 생산한다면, $70 \%$ 의 메탄 전 환율에 의해 메탄 1 몰당 수소 2.8 몰을 생산할 수 있어 바이오 가스 개질 공정을 통해 연간 67 만톤 $\left(2,698,393,876 \mathrm{~m}^{3} \mathrm{CH}_{4} /\right.$ 년 $\times 2.8 \mathrm{~mol} \mathrm{H}_{2} / \mathrm{mol} \mathrm{CH}_{4} \times 1 \mathrm{~mol} \mathrm{CH}_{4} / 22.4 \mathrm{~L} \mathrm{CH}_{4} \times 2 \mathrm{~g} \mathrm{H}_{2} / \mathrm{mol}$ $\mathrm{H}_{2}$ )의 수소를 생산할 수 있다(Table 5).

\section{2. 온실가스 저감량}

유기성폐기물 수소 생산과정에서 발생하는 온실가스양은 음식물류폐기물, 가축분뇨, 하수슬러지의 경우 각각 연간 25 만톤 $\mathrm{CO}_{2}$-eq $\left(10,449\right.$ 톤 $\mathrm{H}_{2} /$ 년 $\times 0.83 \mathrm{~kg} \mathrm{CO}_{2}$-eq $/ \mathrm{kg} \mathrm{H}_{2}+$ 57,472 톤 $\mathrm{H}_{2} /$ 년 $\times 4.15 \mathrm{~kg} \mathrm{CO}_{2}$-eq/kg H ), 247만톤 $\mathrm{CO}_{2}$-eq, 12 만톤 $\mathrm{CO}_{2}$-eq이다. 유기성폐기물로부터 생성된 수소는 재생 가능한 에너지원으로 국내 기존 에너지 생산방법을 대체해 사용하게 된다면, 수소연료전지를 통해 수소의 저위발열량 (LHV)인 $33.3 \mathrm{kWh} / \mathrm{kg} \mathrm{H}_{2}$ 의 $45 \%$ 의 효율로 전력생산이 가능 하다. 따라서 각 유기성폐기물로부터 생산된 수소로 얻을 수 있는 전력량은 음식물류폐기물의 경우 연간 $1,018 \mathrm{GWh}$ $\left(67,921\right.$ 톤 $\mathrm{H}_{2} /$ 년 $\left.\times 33.3 \mathrm{kWh} / \mathrm{kg} \mathrm{H} \mathrm{H}_{2} \times 0.45\right)$, 가축분뇨 연간 $9,301 \mathrm{GWh}$, 하수슬러지 연간 $444 \mathrm{GWh}$ 를 생산 가능하다. 이 로부터 저감될 수 있는 온실가스양은 음식물류폐기물, 가축분 뇨, 하수슬러지 각각 연간 47 만톤 $\mathrm{CO}_{2}$-eq $(1,018 \mathrm{GWh}$ 년 $\times$ $\left.0.46 \mathrm{~kg} \mathrm{CO}_{2} / \mathrm{kWh}\right), 427$ 만톤 $\mathrm{CO}_{2}$-eq, 20 만톤 $\mathrm{CO}_{2}$-eq으로 산정 된다. 식 (11)을 이용해 유기성폐기물 수소생산을 통해 실제 저감될 수 있는 온실가스 양은 음식물류폐기물, 가축분뇨, 하 수슬러지 각각 연간 22 만톤 $\mathrm{CO}_{2}$-eq, 180 만톤 $\mathrm{CO}_{2}$-eq, 9 만톤 $\mathrm{CO}_{2}$-eq으로 총 저감시킬 수 있는 연간 온실가스양은 211 만톤 $\mathrm{CO}_{2-\mathrm{eq}}$ 으로 기대되며 유기성폐기물을 이용한 수소 생산공정 에서 소모되는 에너지원을 재생에너지원으로 대체하게 된다 면 저감할 수 있는 온실가스양은 500 만톤 $\mathrm{CO}_{2}$-eq으로 산정 
Table 6. Total reduction of GHG emission of dark fermentation and steam biogas reforming process through biohydrogen production from organic wastes.

\begin{tabular}{|c|c|c|c|c|}
\hline \multicolumn{2}{|c|}{ Type } & Food waste & Livestock manure & Sewage sludge \\
\hline \multirow{5}{*}{ DF } & $\begin{array}{l}\mathrm{H}_{2} \text { production } \\
\text { (ton/year) }\end{array}$ & 10,449 & 31,444 & 1,741 \\
\hline & $\begin{array}{c}\mathrm{H}_{2} \text { power production } \\
(\mathrm{kWh} / \text { year })\end{array}$ & $156,583,750$ & $471,193,430$ & $26,093,694$ \\
\hline & $\begin{array}{l}\text { GHG reduction } \\
\text { (ton } \mathrm{CO}_{2} \text {-eq/year) }\end{array}$ & 71,936 & 216,471 & 11,988 \\
\hline & $\begin{array}{l}\text { GHG emission } \\
\text { (ton } \mathrm{CO}_{2} \text {-eq/year) }\end{array}$ & 8,673 & 26,099 & 1,445 \\
\hline & $\begin{array}{l}\text { Total GHG reduction } \\
\text { (ton } \mathrm{CO}_{2} \text {-eq/year) }\end{array}$ & 63,263 & 190,372 & 10,542 \\
\hline \multirow{6}{*}{ SBR } & $\begin{array}{l}\mathrm{H}_{2} \text { production } \\
\text { (ton/year) }\end{array}$ & 57,472 & 589,266 & 27,861 \\
\hline & $\begin{array}{c}\mathrm{H}_{2} \text { power production } \\
(\mathrm{kWh} / \text { year })\end{array}$ & $861,210,622$ & $8,830,148,337$ & $417,499,099$ \\
\hline & $\begin{array}{l}\text { GHG reduction } \\
\text { (ton } \mathrm{CO}_{2} \text {-eq/year) }\end{array}$ & 395,649 & $4,056,658$ & 191,803 \\
\hline & $\begin{array}{c}\text { GHG emission } \\
\text { (ton } \mathrm{CO}_{2} \text {-eq/year) }\end{array}$ & 238,507 & $2,445,453$ & 115,624 \\
\hline & $\begin{array}{l}\text { Total GHG reduction } \\
\text { (ton } \mathrm{CO}_{2} \text {-eq/year) }\end{array}$ & 157,142 & $1,611,205$ & 76,180 \\
\hline & $\begin{array}{l}\text { reduction } \\
\text {-eq/year) }\end{array}$ & & $2,108,705$ & \\
\hline
\end{tabular}

Table 7. Summary of biohydrogen production and GHG reduction using dark fermentation and steam biogas reforming process for treating organic wastes.

\begin{tabular}{|c|c|c|c|c|c|}
\hline & Organic waste type & Units & DF & SBR & Total \\
\hline \multirow{3}{*}{$\mathrm{H}_{2}$ production } & Food waste & \multirow{3}{*}{ ton/year } & 10,449 & 57,472 & \multirow{3}{*}{718,233} \\
\hline & Livestock manure & & 31,444 & 589,266 & \\
\hline & Sewage sludge & & 1,741 & 27,861 & \\
\hline \multirow{3}{*}{ GHG reduction } & Food waste & \multirow{3}{*}{$\begin{array}{c}\text { ton } \mathrm{CO}_{2} \text {-eq } \\
\text { /year }\end{array}$} & 63,263 & 157,142 & \multirow{3}{*}{$2,108,705$} \\
\hline & Livestock manure & & 190,372 & $1,611,205$ & \\
\hline & Sewage sludge & & 10,542 & 76,180 & \\
\hline
\end{tabular}

\section{된다(Table 6).}

\section{4. 고 찰}

본 연구에서 분석한 유기성폐기물을 이용한 수소 생산량 및 수소생산 시 절감할 수 있는 온실가스양은 유기성폐기물인 음식물류폐기물, 가축분뇨, 하수슬러지의 연간발생량과 일반 적인 성상을 암발효와 바이오가스 개질 공정에 적용하였고 각 공정 운전으로 인해 발생하는 온실가스 배출량을 고려하여 Table 7과 같은 최종적인 결과를 도출하였다.

암발효를 통해 유기성폐기물로부터 생산될 수 있는 수소의 양은 가축분뇨(72\%), 음식물류폐기물(24\%), 하수 슬러지(4\%) 순으로 많은 것으로 나타났으며, 생산되는 총 수소는 연간 약
4만톤으로 많은 양은 아니지만 매우 친환경적이고 에너지가 적게 드는 수소 생산방법으로 타 생물학적 발효 공정에 비해 기술적 완성도가 높아서 상용화가 실현될 것으로 판단된다. 특히 암발효 후 남는 유기산들은 메탄소화가 아닌 석유화학제 품, 바이오플라스틱 등의 재료로 활용이 가능하므로 바이오리 파이너리 개발 시에도 핵심이 될 수 있는 공정이다. ${ }^{50)}$ 바이오 가스 개질을 통해서는 가축분뇨(87\%), 음식물류폐기물(9\%), 하수 슬러지(4\%)순으로 연간 약 67만톤의 수소생산이 가능 해, 유기성폐기물로부터 생산될 수 있는 수소 총량은 연간 약 72만톤으로 2040년 국내 수소 생산 목표량인 526만톤의 약 $14 \%$ 를 차지할 수 있다. 또한 유기성폐기물을 이용한 수소생 산으로 기존의 에너지원을 대체하여 사용할 경우 저감될 수 있는 온실가스의 양은 암발효를 통해 연간 26만톤 $\mathrm{CO}_{2}$-eq, 
바이오가스 개질을 통해 연간 184 만톤 $\mathrm{CO}_{2}$-eq으로 총 211 만 톤 $\mathrm{CO}_{2}$-eq의 온실가스를 저감시킬 수 있다. 또한 생산과정에 서 이용되는 에너지원을 재생에너지로 공급하게 된다면 저감 될 수 있는 온실가스는 500 만톤 $\mathrm{CO}_{2}$-eq으로 증가하게되며 공 정 자체에서 발생하는 이산화탄소는 탄소중립이고, 생산과정 에서 재생에너지를 이용했기 때문에 그린수소로 인정받을 수 있을 것으로 기대된다.

하지만 현재 발표된 ‘수소 기술개발 로드맵’에서 2019년도 수소 생산분야 정부 R\&D 투자금액 또한 물분해 184 억원, 연 료이용 45억원으로 예년대비 증가한 반면, 폐자원/바이오매 스는 순감한 것으로 보아 현재 국내에서의 폐자원/바이오매 스의 관심도가 감소한 것으로 보인다. 이는 '수소 경제 활성 화 로드맵'에 따르면 국가에서 고려하고 있는 친환경 수소 는 그린수소인 해외 생산수소와 수전해와 화석연료를 원료 로 하는 수소 생산방식인 그레이수소에서 발생하는 이산화 탄소를 제거한(CCS) 블루수소로 한정되어 있어 그 외의 친 환경 $\mathrm{CO}_{2}$-free 수소 공급에 대한 구체적인 기준이 규정되어 있지 않기 때문인 것으로 판단된다. 따라서 유럽연합(EU)의 "CertifHy 프리미엄 수소” 확정 방식 ${ }^{51}$ 과 같이 현재 단계에서 는 완전한 그린수소만을 목표로 하는 것이 아니라 폐자원/바 이오매스를 통한 저탄소 수소생산 방식을 도입하는 방식도 고려한다면 2040년 국내에서 목표로 하고있는 그린수소 생산 량인 368 만톤의 약 $20 \%$ 에 해당하는 수소가 생산 가능할 것으 로 예상된다. 따라서 기술 연구뿐만 아니라 정책 연구 또한 진행된다면 유기성폐기물을 통해 친환경 수소 생산방식을 통 한 수소 생산량 확보를 더욱 빨리 현실화할 수 있을 것으로 기대된다.

\section{5. 결 론}

본 연구에서는 재생자원인 유기성폐기물로부터 생산될 수 있는 그린수소의 양과 이에 따라 저감될 수 있는 온실가스 양을 분석해보았다. 암발효를 통해 생산될 수 있는 수소의 양 은 연간 약 4 만톤(음식물류폐기물 1.0 만톤, 가축분뇨 3.1만톤, 하수슬러지 0.2 만톤), 바이오가스 개질을 통해 생산되는 수소 는 연간 67 만톤(음식물류폐기물 5.7 만톤, 가축분뇨 59.0 만톤, 하수슬러지 2.8만톤)으로 산정되었다. 유기성폐기물 종류별 수소 생산량은 가축분뇨가 $86 \%$ 로 가장 높게 나타나며 음식물 류폐기물 $10 \%$, 하수슬러지 $4 \%$ 순으로 나타났다. 생산된 수소 의 총량은 연간 72 만톤으로 2040 년 국내 수소생산 목표량인 526 만톤의 $14 \%$, 그린수소 생산 목표량인 368 만톤의 $20 \%$ 를 충당할 수 있는 것으로 파악되었다. 유기성폐기물을 이용해 생산된 수소의 발전으로부터 얻을 수 있는 총 온실가스 저감 량은 연간 500 만톤 $\mathrm{CO}_{2}$-eq으로 나타났으며, 수소 제조 공정 시 소요되는 에너지로 인해 배출되는 온실가스의 양을 차감하 면 최종적으로 연간 211만톤 $\mathrm{CO}_{2}$-eq(암발효 26만톤 $\mathrm{CO}_{2}$-eq,
바이오가스 개질 184 만톤 $\mathrm{CO}_{2}$-eq)의 온실가스 저감이 가능할 것으로 예상된다.

\section{Acknowledgement}

이 논문은 2021년도 정부(미래창조과학부)의 재원으로 한 국연구재단의 지원을 받아 수행된 기초연구사업임(NRF-2021 R1A2C2013341).

\section{References}

1. IPCC, Global warming of $1.5^{\circ} \mathrm{C}$ SPM, (2018).

2. GOV. KR., The revised national roadmap for greenhouse gas reduction by 2030, (2018).

3. Ministry of Environment, Ministry of environment carbon neutral action plan 2021, (2021).

4. F. Vendruscolo, Biohydrogen production from starch residues, International Journal of Chemical, Molecular, Nuclear, Materials and Metallurgical Engineering, 8(12), 1356e1362(2014).

5. GOV. KR., Road mobility in hydrogen economy, (2019).

6. A. Arregi, M. Amutio, G. Lopez, J. Bilbao, M. Olazar, Evaluation of thermochemical routes for hydrogen production from biomass: A review, Energy conversion and management, 165, 696-719(2018).

7. J. A. Kwon, Y. J. Shin, D. Y. Shin, Y. M. Kim, C. H. Park, S. J. Hwang, G. U. Gil, D. H. Lim, Enhanced reaction of renewable hydrogen energy production using platinum-based nanoclusters, J. Korean Soc. Environ. Eng., 41(12), 686-694(2019).

8. S. H. Park, J. Y. Ryu, G. Sohn, Techno-economic analysis (TEA) on hybrid process for hydrogen production combined with biomass gasification using oxygen released from the water electrolysis based on renewable energy, KIGAS, 24(5), 65-73(2020).

9. Ministry of Environment, KEITI, Analysis of hydrogen energy technology, (2020).

10. W. Zhang, Automotive fuels from biomass via gasification, Fuel processing technology, 91(8), 866-876(2010).

11. K. R. Kim, S. J. Sim, Biological hydrogen production technology-present and future, News \& Information for Chemical Engineers, 27(4), 414-420(2009).

12. T. H. Kim, B. S. Lim, H. S. Park, Y. M. Yun, Enhanced bio-hydrogen production from pretreated microalgal waste, J. Korean Soc. Environ. Eng., 41(9), 494-500(2019).

13. H. G. Song, Y. N. Chun, Biogas reforming conversion character on microwave-heating carbon receptor, J. Korean Soc. Environ. Eng., 42(2), 40-46(2020).

14. K. C. Mondal, S. R. Chandran, Evaluation of the economic impact of hydrogen production by methane decomposition with steam reforming of methane process, International journal of hydrogen energy, 39(18), 9670-9674(2014).

15. S. Sharma, S. Basu, N. P. Shetti, T. M. Aminabhavi, 
Waste-to-energy nexus for circular economy and environmental protection: recent trends in hydrogen energy, Science of The Total Environment, 713, 136633(2020).

16. C. H. Kim, K. Y. Ko, J. K. Lee, H. G. Chung, Screening of effective media for black soldier fly larvae used in food waste treatment, J. Korean Soc. Environ. Eng., 42(10), 463-471(2020).

17. Ministry of Trade, Industry and Energy, Korea Energy Agency, 2018 New \& renewable energy white paper, (2019).

18. Korea resource recirculation information system, Domestic waste generation and treatment 2019, (2020).

19. Ministry of Environment, Statistics of livestock manure generation and treatment trend 2019, (2020).

20. Ministry of Environment, Statistics of sewerage 2019, (2020).

21. Ministry of Environment, The technology manual of food waste biogas pant, (2016).

22. S. Kim, Development of anaerobic digestion technology for production of high calorific biogas via autogenerative pressure and hydrogen supplementation, Inha Univ. master's thesis, (2021).

23. S. Im, Reducing greenhouse gases and odor emissions, and preserving biogas potential of livestock manure by improving storage method, Inha Univ. doctoral dissertation, (2020).

24. S. Im, S. O. Petersen, D. Lee, D. H. Kim, Effects of storage temperature on $\mathrm{CH}_{4}$ emissions from cattle manure and subsequent biogas production potential, Waste management, 101, 35-43(2020).

25. C. J. Busato, C. Da Ros, R. Pellay, P. Barbierato, P. Pavan, Anaerobic membrane reactor: Biomethane from chicken manure and high-quality effluent, Renewable Energy, 145, 1647-1657(2020).

26. J. R. Park, D. H. Lee, K. H. Kim, Evaluation of bio-drying process of sewage sludge using mathematical model of heat and mass balance: effect of temperatures of supplied air and exhaust gas, J. Korean Soc. Environ. Eng., 42(11), 580-591(2020).

27. K. Svensson, O. Kjørlaug, M. J. Higgins, R. Linjordet, S. J. Horn, Post-anaerobic digestion thermal hydrolysis of sewage sludge and food waste: Effect on methane yields, dewaterability and solids reduction, Water research, 132, 158-166(2018).

28. J. Y. Lee, Hydrogen production from organic wastes by co-culture or two phase system of dark and photo fermentative microorganisms, Kyungpook National Univ. doctoral dissertation, (2010).

29. M. Okamoto, T. Miyahara, O. Mizuno, T. Noike, Biological hydrogen potential of materials characteristic of the organic fraction of municipal solid wastes, Water Science and Technology, 41(3), 25-32(2000).

30. H. S. Hafid, A. R. Nor'Aini, M. N. Mokhtar, A. T. Talib, A. S. Baharuddin, M. S. U. Kalsom, Over production of fermentable sugar for bioethanol production from carbohydrate-rich Malaysian food waste via sequential acid-enzymatic hydrolysis pretreatment, Waste management, 67, 95-105(2017).

31. D. N. Miller, V. H. Varel, In vitro study of the biochemical origin and production limits of odorous compounds in cattle feedlots, Journal of Animal Science, 79(12), 2949-2956(2001).

32. H. Miao, S. Wang, M. Zhao, Z. Huang, H. Ren, Q. Yan, W. Ruan, Codigestion of Taihu blue algae with swine manure for biogas production, Energy Conversion and Management, 77, 643-649(2014).

33. S. H. Kim, S. K. Han, H. S. Shin, Feasibility of biohydrogen production by anaerobic co-digestion of food waste and sewage sludge, International Journal of Hydrogen Energy, 29(15), 1607-1616(2004).

34. D. H. Kim, S. H. Kim, K. Y. Kim, H. S. Shin, Experience of a pilot-scale hydrogen-producing anaerobic sequencing batch reactor (ASBR) treating food waste, International Journal of Hydrogen Energy, 35(4), 1590-1594(2010).

35. S. Jang, D. H. Kim, Y. M. Yun, M. K. Lee, C. Moon, W. S. Kang, S. S. Kwak, M. S. Kim, Hydrogen fermentation of food waste by alkali-shock pretreatment: microbial community analysis and limitation of continuous operation, Bioresource technology, 186, 215-222(2015).

36. Z. Shi, L. Zhang, H. Yuan, X. Li, Y. Chang, X. Zuo, Oyster shells improve anaerobic dark fermentation performances of food waste: Hydrogen production, acidification performances, and microbial community characteristics, Bioresource Technology, 335, 125268(2021).

37. Y. Wang, Y. Zhang, L. Meng, J. Wang, W. Zhang, Hydrogen - methane production from swine manure: Effect of pretreatment and VFAs accumulation on gas yield, Biomass and Bioenergy, 33(9), 1131-1138(2009).

38. Y. Xing, Z. Li, Y. Fan, H. Hou, Biohydrogen production from dairy manures with acidification pretreatment by anaerobic fermentation, Environmental Science and Pollution Research, 17(2), 392-399(2010).

39. L. Guo, J. Zhao, Z. She, M. Lu, Y. Zong, Effect of S-TE (solubilization by thermophilic enzyme) digestion conditions on hydrogen production from waste sludge, Bioresource technology, 117, 368-372(2012).

40. Y. Yin, J. Wang, Fermentative hydrogen production from waste sludge solubilized by low-pressure wet oxidation treatment, Energy \& Fuels, 30(7), 5878-5884(2016).

41. Ministry of Environment, Technical manual of co-digestion biogas plant, (2016).

42. S. K. Ryi, J. Y. Han, C. H. Kim, H. Lim, H. Y. Jung, Technical trends of hydrogen production, Clean Technol., 23(2), 121-132(2017).

43. A. Effendi, K. Hellgardt, Z. G. Zhang, T. Yoshida, Optimising $\mathrm{H} 2$ production from model biogas via combined steam reforming and CO shift reactions, Fuel, 84(7-8), 869-874(2005)

44. National Institute of Animal Science, A comparision of domestic livestock manure biogas plant, (2010).

45. National Research Council, The hydrogen economy: opportunities, costs, barriers, and R\&D needs, National 
Academies Press, pp. 240(2004).

46. I. Staffell, D. Scamman, A. V. Abad, P. Balcombe, P. E. Dodds, P. Ekins, N. Shah, K. R. Ward, The role of hydrogen and fuel cells in the global energy system, Energy \& Environmental Science, 12(2), 463-491(2019).

47. Korea Environment Corporation, Ministry of Environment, ETS Insight (Climate change \& Carbon market), (2020).

48. Sudokwon Landfill Site Management Corp., Food waste leachate biogas plant operation and management technology, (2021).

49. D. P. Minh, T. J. Siang, D. V. N. Vo, T. S. Phan, C. Ridart, A. Nzihou, D. Grouset, Hydrogen production from biogas reforming: An overview of steam reforming, dry reforming, dual reforming, and tri-reforming of methane, Hydrogen Supply Chains, 111-166(2018).

50. M. S. Kim, J. G. Na, M. K. Lee, H. Ryu, Y. K. Chang, J. M. Triolo, Y. M. Yun, D. H. Kim, More value from food waste: Lactic acid and biogas recovery, Water research, 96, 208-216(2016).

51. CertifHy, https://www.certifhy.eu/, (2017).

\section{Declaration of Competing Interest}

The authors declare that they have no known competing financial interests or personal relationships that could have appeared to influence the work reported in this paper.

\section{Authors and Contribution Statement}

\section{Jimin Kim}

Department of Smart-city Engineering, Inha University, M.S. Student, ORCID® 0000-0001-8599-5120: Data analysis, Methodology, Visualization, Writing - original draft

\section{Seongwon Im}

Department of Smart-city Engineering, Inha University, Ph.D., ORCiD (이 0000-0002-2734-8555: Conceptualization, Methodology, Writing - review and editing

\section{Alsayed Mostafa}

Department of Smart-city Engineering, Inha University, Ph.D. Student, ORCID (10 0000-0002-3727-6954: Data analysis, Writing review and editing

\section{Om Prakash}

Department of Smart-city Engineering, Inha University, Ph.D. Student, ORCID (1) 0000-0002-9005-1148: Data analysis, Writing review and editing

\section{Dong-Hoon Kim}

Department of Smart-city Engineering, Inha University, Associate Professor, ORCID () 0000-0002-0471-9982: Conceptualization, Resources, Project administration, Supervision, Writing - review and editing 